\title{
QUANTITATIVE STUDIES OF THE EFFECT OF RED-BLOOD-CELL SENSITIZATION ON IN VIVO HEMOLYSIS *
}

\author{
By M. CONSTANTOULAKIS, $\dagger$ N. COSTEA, $\neq$ R. S. SCHWARTZ, AND \\ W. DAMESHEK \\ (From the Blood Research Laboratory, Pratt Clinic-New England Center Hospital, and the \\ Department of Medicine, Tufts University School of Medicine, \\ Boston, Mass.)
}

(Submitted for publication January 22, 1963 ; accepted July 29, 1963)

Although a positive antiglobulin reaction is a characteristic and distinctive feature of autoimmune hemolytic anemia (AIHA), the precise role of the erythrocyte-sensitizing globulin in the pathogenesis of this disease is poorly understood. Earlier studies have suggested that the severity of hemolysis in AIHA is a function of the quantity of globulin adherent to the red blood cells (1) ; however, direct estimation of the amount of autoantibody was possible in only a few cases. There is, in addition, a lack of quantitative data concerning the effects of isoantibodies on erythrocyte survival. In the experiments described in this paper, the relationships between red-cell sensitization, by either auto- or isoantibodies, and in vivo hemolysis were examined through the techniques of $\mathrm{Cr}^{51}$-labeled red-cell survival and the radioactive antiglobulin (RAG) test (2). In this test, rabbit antihuman globulin labeled with radioactive iodine is used. After appropriate incubation and washing, the amount of rabbit antihuman globulin reacting with the sensitized red cells may be ascertained from the specific radioactivity of these cells. The amount of human antibody sensitizing the red blood cells is calculated from the combining ratio between the rabbit antibody and the erythrocyte-bound human gamma globulin. When the human antibody was of the gamma ${ }_{2}$ globulin variety, this ratio was found to be 7 to 1 , i.e., 7 molecules of rabbit antiglobulin reacted with 1 molecule of red-cell-bound antibody. The results of these experiments indicated that, irrespective of their serologic attri-

* Aided by American Cancer Society grant T-243 and U. S. Public Health Service grant E-3091.

† Present address: 2 Ersis Street, Athens 7, Greece.

$\ddagger$ Present address: West Side VA Hospital, South Damen Avenue, Chicago 12, Ill. butes, both isoantibodies and autoantibodies had qualitatively distinctive effects on red-cell survival.

\section{MATERIALS AND METHODS}

Patients. Seventeen patients with AIHA of the "warm" antibody variety were studied; 11 were "idiopathic," and the rest had systemic lupus erythematosus (2), chronic lymphocytic leukemia (3), or Hodgkin's disease (1). Characteristics of the individual cases are shown in Table I.

Isoantibodies. The anti-D and anti-Kell sera were of the incomplete, noncomplement-binding variety. ${ }^{1}$

Eluates were prepared by Fudenberg, Barry, and Dameshek's modification (1) of the Kidd (3) method and were stored at $-20^{\circ} \mathrm{C}$ until used. Each of the eluates was tested serologically and physicochemically as follows. a) Serology. Eluates were titrated by the standard indirect antiglobulin technique (4), in which a constant pool of red cells ${ }^{2}$ (Hemantigen) and commercial antiglobulin serum ${ }^{3}$ were used. The tests were carried out at $4^{\circ}, 22^{\circ}$, and $37^{\circ} \mathrm{C}$. In some instances, fresh human serum was added as a source of complement. The serologic specificity of the eluates was determined by the indirect antiglobulin reaction using a panel of red cells of known antigenic composition 4 (Panocell). The antigens present in this panel were: $\mathrm{C}, \mathrm{C}^{\mathrm{w}}, \mathrm{D}, \mathrm{E}, \mathrm{V}, \mathrm{c}, \mathrm{e}$, $\mathrm{f}, \mathrm{K}, \mathrm{k}, \mathrm{Fy}^{\mathrm{a}}, \mathrm{Fy}^{\mathrm{b}}, \mathrm{Js}^{\mathrm{a}}, \mathrm{Le}^{\mathrm{a}}, \mathrm{Le}^{\mathrm{b}}, \mathrm{Jk}^{\mathrm{a}}, \mathrm{Jk}^{\mathrm{b}}, \mathrm{M}, \mathrm{N}, \mathrm{S}, \mathrm{s}, \mathrm{P}$, and $\mathrm{Lu}^{\mathrm{a}}$. Normal red cells (Hemantigen) incubated with the eluates were also tested for sensitization by the standard antiglobulin technique with specific goat antihuman 7S and antihuman 19S sera. ${ }^{5}$ b) Physicochemical studies. Electrophoresis by standard techniques on paper and cellulose-acetate supporting media were carried out on a Durrum-type cell. Protein concentrations were determined by the method of Lowry, Rosebrough, Farr, and Randall (5). A standard curve, utilizing a

\footnotetext{
${ }^{1}$ Kindly provided by the Ortho-Research Foundation, Raritan, N. J., and the Blood Grouping Laboratory, Boston, Mass.

${ }^{2}$ Hemantigen, Knickerbocker, New York, N. Y.

3 Broad spectrum, Ortho-Research Foundation, Raritan, N. J.

4 Panocell, Knickerbocker, New York, N. Y.

5 Hyland Laboratories, Los Angeles, Cal.
} 
TABLE I

Some clinical and laboratory features in 17 patients with $A I H A^{*}$

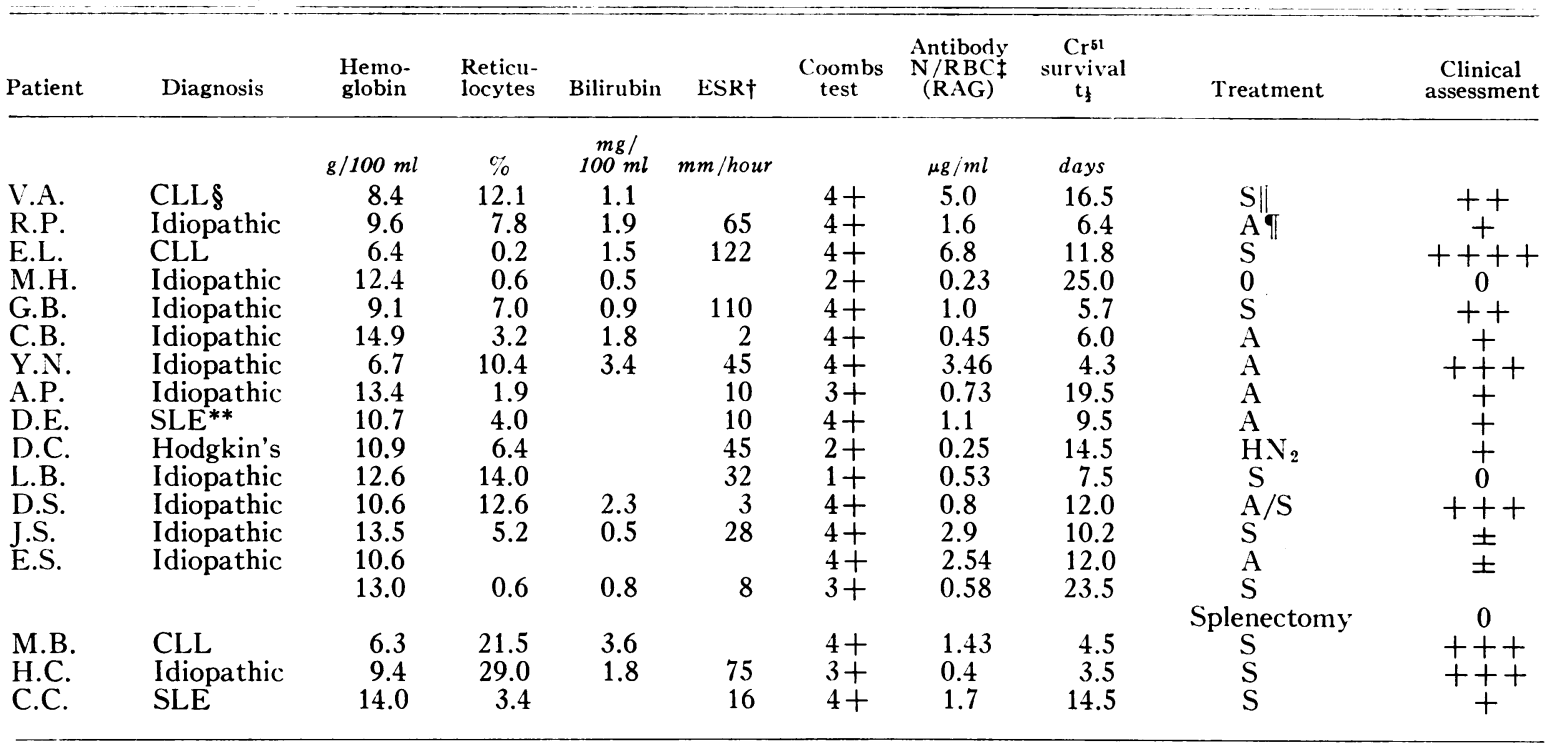

* The clinical assessment was arbitrarily judged to range from complete remission $(0)$ to severe illness $(++++)$. $\mathrm{AIHA}=$ autoimmune hemolytic anemia.

$\dagger \mathrm{ESR}=$ erythrocyte sedimentation rate.

$\mathrm{N}=$ nitrogen $; \mathrm{RBC}=$ red blood cells; $\mathrm{RAG}=$ radioactive antiglobulin.

\&LL = chronic lymphocytic leukemia.

If $\mathrm{S}=$ steroids.

T $\mathrm{A}=$ antimetabolites.

** SLE $=$ systemic lupus erythematosus.

solution in which the protein-nitrogen concentration was determined by the micro-Kjeldahl technique, was prepared for each new batch of Lowry reagents. Immunodiffusion in agar plates was performed with a modification of the Ouchterlony method (6). Specific antihuman 7S and antihuman 19S globulins sera of goat origin were employed. Since some eluates were slightly contaminated with free hemoglobin, each gel-diffusion test was controlled for the possible precipitation of methemalbumin in the agar medium by allowing the eluate to react against normal human serum in a separate agar plate. In no instance was a precipitin line observed in these control tests. Eluates were next incubated with equal volumes of $0.2 \mathrm{M}$ mercaptoethanol $(7,8)$ at room temperature for 48 hours in tightly sealed tubes, then dialyzed in the cold against $20 \mathrm{~L}$ of phosphate buffer ( $\mathrm{pH} 7.2$ ) containing $0.02 \mathrm{M}$ iodoacetate. Controls in which saline was substituted for 2-mercaptoethanol were run simultaneously. As an additional control, a serum containing a high titer of cold agglutinin was treated in a similar manner and then tested for cold agglutinin activity. Indirect antiglobulin tests were carried out, as described above, on the eluates treated in this manner.

$R A G$ tests (2) were performed on red cells from patients with AIHA immediately before the red-cell survivals were started and on the artificially sensitized normal erythrocytes just before the $\mathrm{Cr}^{51}$ labeling procedure.
Determination of the combining ratio of $R A G$ with the red-cell antibodies. The globulin fractions of potent anti-D and anti- $\mathrm{K}$ sera obtained from individual donors were dissolved in borate buffer, $\mathrm{pH}$ 8. Immunoelectrophoretic analysis of these fractions showed only one component, gamma 2 globulin. These preparations were labeled with $\mathrm{I}^{125}$ by the method of Helmkamp and his associates (9). In some experiments, the anti-D sera were treated by absorption on thoroughly washed Rhpositive red cells and subsequent elution by Fudenberg and his co-workers' (1) modification of the Kidd (3) technique. Other experiments showed that this preliminary isolation of the antibody did not affect the results, and later studies dealing with the combining ratio were performed directly with the labeled globulin fractions. The radioactive antibody solutions containing $6 \%$ bovine or human serum albumin, added to minimize utake of nonspecific proteins $(2,10)$, were incubated with 0.1 $\mathrm{ml}$ portions of packed red cells. After 15 minutes of incubation at $37^{\circ} \mathrm{C}$, the cells were washed in chilled 0.15 $M$ saline until the radioactivity of the red-cell button remained constant. All washing procedures were carried out in a refrigerated centrifuge. The amount of antibody protein attached to the red-cell surface was then determined from the SA of the antibody solution. After this, the cells were incubated with RAG labeled with $\mathrm{I}^{131}$ for 30 minutes at $37^{\circ} \mathrm{C}$. The cells were next washed in cold saline until less than $5 \%$ of the radio- 
activity was recovered in the supernatant fluid of two successive washings. After each washing, the amounts of $\mathrm{I}^{125}$ and $\mathrm{I}^{131}$ were determined in a single-channel spectrometer. Interference of the $\mathrm{I}^{131}$ radiation spectrum with that of $\mathrm{I}^{125}$, which was less than $10 \%$, was corrected by appropriate calculations. Radioactivity was converted to micrograms of protein nitrogen according to previously described methods (2).

Survival of artificially sensitized, normal erythrocytes. Three to five $\mathrm{ml}$ of blood from normal donors was taken in acid-citrate dextrose, ${ }^{6}$ washed twice, and incubated with a solution of the desired isoantibody for 15 minutes at $37^{\circ} \mathrm{C}$. After the cells were washed twice, a small sample was removed for RAG determination. The remaining cells were labeled with $\mathrm{Cr}^{51}$ (11). The sensitized, labeled erythrocytes were injected into the donor, and samples were taken at different time intervals, depending upon the rapidity of disappearance of the labeled cells from the circulation. A simultaneous determination of blood volume was carried out with each red-cell survival study; this value was then compared with the expected blood volume (12) to calculate the fraction of red cells destroyed within the first 10 minutes of their injection.

Survival studies with erythrocytes from patients with AIHA. Ten to fifteen $\mathrm{ml}$ of the patient's blood was labeled with 30 to $60 \mu \mathrm{c}$ of $\mathrm{Cr}^{51}$. One sample was injected into the patient (autosurvival), and another was administered to a normal recipient of the same ABO and $\mathrm{Rh}$ groups as the patient (isosurvival). A simultaneous blood-volume determination was carried out in each recipient. Samples were taken at various time intervals, depending upon the rapidity of destruction of the injected cells. Patients with findings in any way indicative of past or present hepatitis were excluded from this part of the study, as were normal recipients who gave histories of previous blood transfusions.

Determination of radioactivity. Radioactivity of the specimens was counted in a well-type, iodide-crystal

${ }^{6}$ Abbott Laboratories, North Chicago, Ill. scintillation counter, ${ }^{7}$ and the time of counting was set to maintain the counting error within $5 \%$. Reference standards were prepared for purposes of decay correction.

\section{RESULTS}

Characterization of eluates in AIHA (Tabie $I I)$. All eluates reacted in the indirect antiglobulin test, the highest titer being 128, the lowest, 4 . During these studies, we found that reprocessing of samples of erythrocyte stroma through additional cycles of the elution procedure, in some instances as many as five cycles, yielded serologically active eluates. Apparently, a single elution of the red-cell stroma brought only partial recovery of antibody. We therefore made no further attempts to quantitate erythrocyte-coating globulins by an elution technique. No serologic activity was detected in the eluates prepared from the red cells of four normal individuals. Test red cells were incubated with the eluates at $4^{\circ}, 22^{\circ}$, and $37^{\circ} \mathrm{C}$, and in no instance were significant deviations in specificity or antiglobulin titer noted as the result of these temperature differences. The protein content of the eluates ranged from 41.3 to $101.3 \mu \mathrm{g}$ $\mathrm{N}$ (nitrogen) per $\mathrm{ml}$. No serologic specificity could be demonstrated in seventeen of the twenty eluates studied. Of the remaining three, one behaved like anti-e (the patient's red cells were e-positive), and two showed some specificity that could not be completely characterized.

Although the red-cell sensitizing protein was obviously a gamma globulin, since it reacted with

${ }^{7}$ Scintillation detector 810B, Baird Atomic, Cambridge, Mass.

TABLE II

Eluate characteristics in ten patients with AIHA

\begin{tabular}{|c|c|c|c|c|c|c|c|c|c|}
\hline \multirow[b]{2}{*}{ Patient } & \multirow[b]{2}{*}{ Protein N } & \multicolumn{2}{|c|}{ Titer } & \multirow[b]{2}{*}{$\begin{array}{l}\text { Titer after } \\
\text { 2-ME* }\end{array}$} & \multicolumn{2}{|c|}{ Indirect Coombs } & \multicolumn{2}{|c|}{ Agar-gel diffusion } & \multirow[b]{2}{*}{ Specificity } \\
\hline & & $37^{\circ}$ & $4^{\circ}$ & & $\underset{7 \mathrm{~S}}{\text { Anti- }}$ & $\begin{array}{c}\text { Anti- } \\
19 S\end{array}$ & $\begin{array}{l}\text { Anti- } \\
7 \mathrm{~S}\end{array}$ & $\begin{array}{c}\text { Anti- } \\
19 \mathrm{~S}\end{array}$ & \\
\hline & $\mu g / m l$ & & & & & & & & \\
\hline E.L. & 41.3 & 64 & 64 & 32 & + & - & + & - & Nonspecific \\
\hline Y.N. & 51.3 & 128 & 128 & 128 & + & - & + & - & Nonspecific \\
\hline A.P. & 90.0 & 4 & 4 & 4 & + & - & - & - & Nonspecific \\
\hline R.P. & 101.3 & 64 & 32 & 64 & + & - & + & - & Nonspecific \\
\hline L.B. & 75.0 & 16 & 16 & 8 & + & - & - & - & Nonspecific \\
\hline G.B. & 77.5 & 32 & 16 & 32 & + & - & - & - & Nonspecific \\
\hline D.S. & 85.0 & 8 & 8 & 8 & + & - & - & - & Nonspecific \\
\hline C.C. & 56.3 & 32 & & 32 & + & - & + & - & Nonspecific \\
\hline D.E. & 73.8 & 4 & & 4 & + & - & - & - & Nonspecific \\
\hline C.B. & & 8 & & 8 & + & - & - & - & Nonspecific \\
\hline Normal & 71.3 & - & - & - & - & - & - & - & \\
\hline
\end{tabular}

* ME = mercaptoethanol. 
rabbit antihuman gamma globulin in the indirect Coombs test, we tried to characterize this material further. On paper electrophoresis, the eluates migrated in the gamma-globulin region, and in some instances, they appeared as a diffuse band extending from the gamma region to the cathodal edge of the beta position. Migration into the leading edge of the beta position was observed when cellulose acetate was the supporting medium.

Four of eleven eluates tested reacted in the double-diffusion gel system with specific goat antihuman $7 \mathrm{~S}$ serum (Figure 1). These reactions were visible as well-defined arcs whose convexity faced the antigen well. This type of precipitin arc indicates that the molecular weight of the antigen (eluate) is equal to or less than the molecular weight of the antiserum (hyperimmune goat serum) and is compatible with the reaction of gamma globulin of the $7 \mathrm{~S}$ variety (13). None of the eluates reacted in this system with specific goat antihuman 19S serum. The failure of seven eluates to show precipitin bands in the agar may have been due either to insufficient quantities of antigen or to inadequate amounts of antibody in the goat serum. When the latter antiserum was used as the "developing" reagent in the indirect antiglobulin

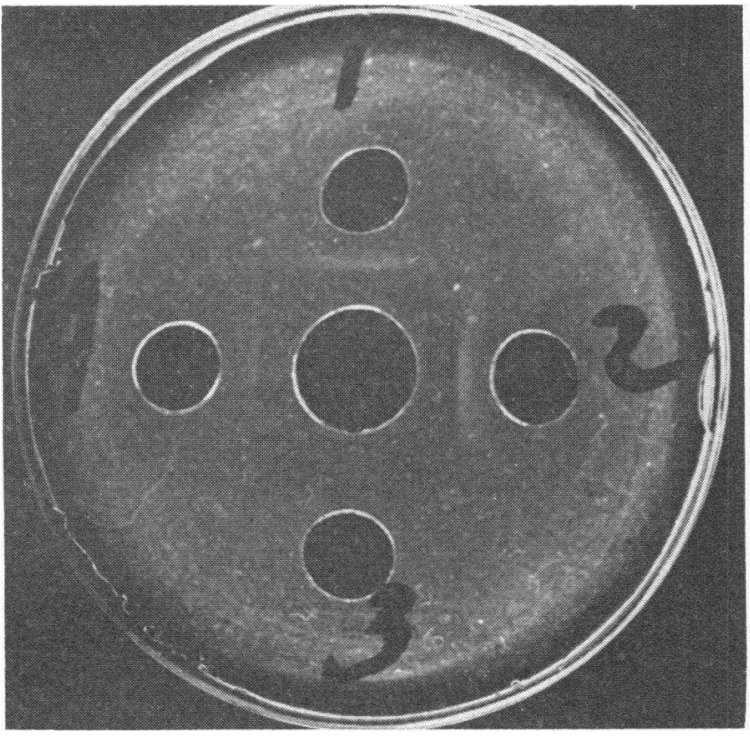

Fig. 1. Two-dimensional agar diffúsion of REd-Cell FLCATE FROM PATIENTS WITH ACTOIMMUNE HEMOLYTIC ANEMIA (AIHA). The center well contains goat antihuman 7S antibody; wells 1,2 , and 4 were charged with eluates from AIHA red cells, whereas well 3 contains an eluate from normal erythrocytes.
TABLE III

The combining ratio of RAG with erythrocyte antibodies*

\begin{tabular}{lcccc}
\hline \hline Experiment & Antibody $\dagger$ & RAG added & $\begin{array}{c}\text { RAG } \\
\text { absorbed }\end{array}$ & $\begin{array}{c}\text { RAG/ } \\
\text { antibody }\end{array}$ \\
\hline \multirow{3}{*}{ Anti-D } & $\mu g$ & $\mu g$ & $\mu g$ & \\
& .130 & 0.6 & 0.27 & 2.1 \\
& .140 & 1.2 & 0.42 & 3.0 \\
& .137 & 3.0 & 0.63 & 4.6 \\
& .130 & 6.0 & 0.75 & 5.8 \\
& .139 & 12.0 & 0.97 & 7.0 \\
& .130 & 18.0 & 0.90 & 6.9 \\
Anti-CD & .132 & 24.0 & 0.92 & 7.1 \\
& .386 & 12.5 & 1.59 & 4.1 \\
& .210 & 13.0 & 1.07 & 5.1 \\
& .160 & 12.8 & 0.99 & 6.2 \\
& .139 & 12.9 & 0.98 & 7.0 \\
& .062 & 12.1 & 0.45 & 7.3 \\
Anti-K & .038 & 12.5 & 0.27 & 7.1 \\
& 0.290 & 0.6 & 0.934 & 3.2 \\
& 0.280 & 1.2 & 0.813 & 2.9 \\
& 0.283 & 3.0 & 1.02 & 3.6 \\
& 0.285 & 6.0 & 1.69 & 5.9 \\
& 0.290 & 12.0 & 2.06 & 7.1 \\
& 0.281 & 18.5 & 1.97 & 7.0 \\
& 0.257 & 24.0 & 1.83 & 7.1 \\
& & & &
\end{tabular}

* Three typical experiments, in which three different isoantibodies were tested, are shown. In the range of antibody excess, the ratio of RAG to sensitizing antibody is approximately 7.0 .

$\dagger$ Antibody nitrogen $/ 0.1 \mathrm{ml}$ packed red cells.

tests of the eluates, all reactions were negative. On the other hand, a rabbit serum reacting specifically with human gamma ${ }_{2}$ globulin gave strong agglutination patterns (Table II). In every instance, incubation of the eluates in $0.1 \mathrm{M} 2$-mercaptoethanol failed to reduce the titer significantly (Table II), although this procedure reduced the cold agglutinin titer of the positive control serum.

The combining ratio of $R A G$ with red-cell isoantibodies. In the experiments shown in Figure 2, and Table III, Rh-positive red cells were sensitized with a standard amount of $\mathrm{I}^{125}$-labeled anti-D; $0.1-\mathrm{ml}$ samples of these cells were then distributed into seven tubes. Different amounts of RAG contained in a constant volume were added to each of them, and the adsorptions of $\mathrm{I}^{125}$ anti-D and $\mathrm{I}^{131}$-RAG were determined. After reaching a maximal value, the amount of antihuman globulin adsorbed by sensitized erythrocytes showed no further increase. In the zone of extreme antibody excess, the ratio between $\mathrm{I}^{131}-\mathrm{RAG}$ and $\mathrm{I}^{125}$-anti-D was found to be 7 to 1 , assuming a mol wt of 160,000 for both the rabbit antihuman globulin and the human anti-D globu- 
lins. The same result was obtained with a second sample of anti-D and a sample of anti-K. The ratio of 7 to 1 was constant regardless of the amount of antibody adherent to the red cell, and in one experiment this ratio remained constant, i.e., 7 to 1 , during the entire washing procedure, since the human antibody dissociated from the red cell in combination with 7 molecules of rabbit antibody.

Isoantibodies. a) Effect of varying amounts of a given isoantibody (anti-D) on red-cell survival. Serum no. 60-665, obtained from an in-

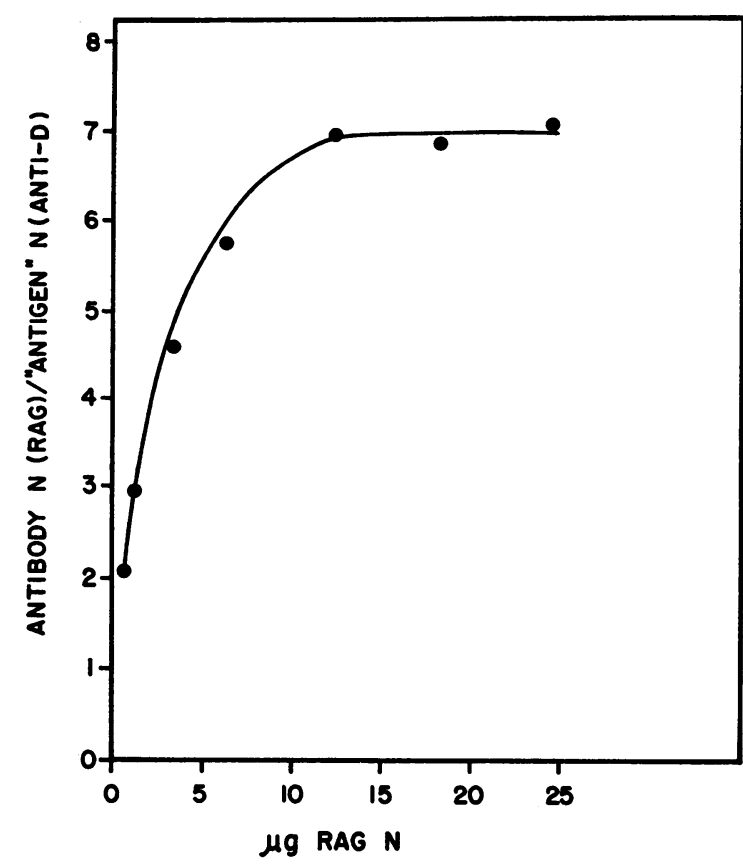

Fig. 2. The combining RATIO OF RADioactive ANTIGLOBULIN (RAG) WITH ANTI-D AT INCREASING CONCENTRATIONS.

dividual donor and containing a powerful incomplete anti-D antibody, was used to sensitize $\mathrm{Rh}$-positive red cells and obtain final concentrations of antibody bound to red cells of $0.21,0.54$, $0.97,1.11,1.37,1.53$, and $3.29 \mu \mathrm{g} \mathrm{N}$ per $\mathrm{ml}$ red cells. These antibody concentrations were calculated from the RAG absorption, assuming a combining ratio of 7 to 1 (RAG to anti-D). The survival of these variously sensitized cells is shown in Figure 3, which demonstrates the relationship between amount of red-cell-bound antibody and red-cell survival $\left(t_{\frac{1}{2}}\right)$. Several characteristics of this relationship bear comment.

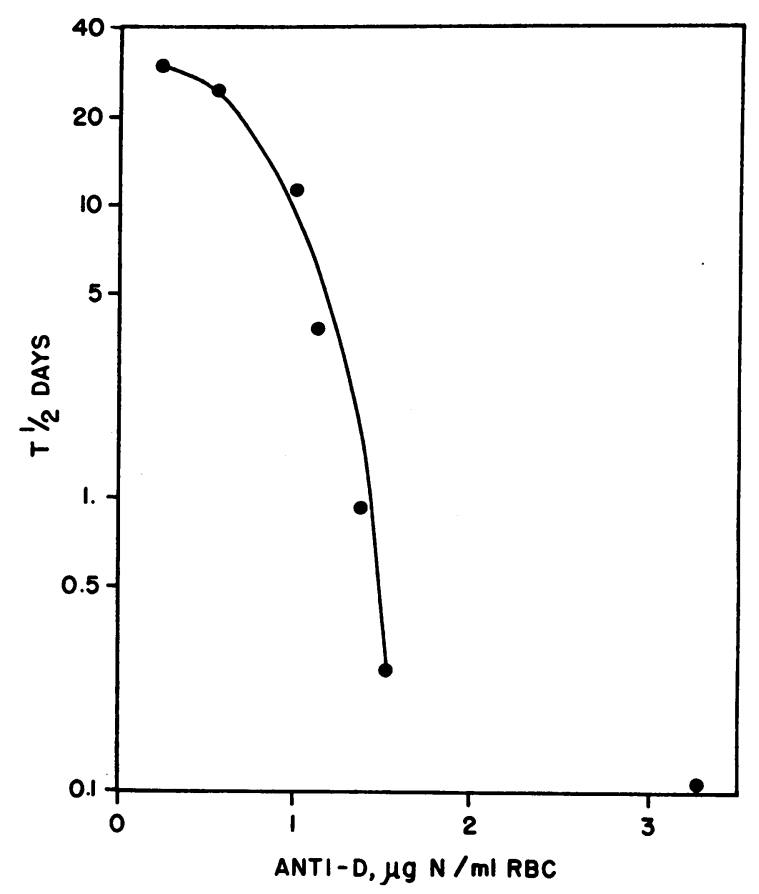

Fig. 3. Relation Between amount of Red-CEllBound ANTI-D AND RED-CEll survival. Serum 60-665 from one sensitized person was used.

Low levels of sensitization ( 0.21 and $0.54 \mu \mathrm{g}$ antibody $\mathrm{N}$ per $\mathrm{ml} \mathrm{RBC}$ ) did not appreciably affect the red-cell survival, even though the antiglobulin test of the injected cells was positive $(0.54 \mu \mathrm{g}$ anti-D $\mathrm{N}$ per $\mathrm{ml} \mathrm{RBC}$ gave a $4+$ antiglobulin reaction). Above a certain level of sensitization, small increments in absorbed antibody produced marked changes in red-cell survival. When antibody concentration was less than one-half the maximal binding capacity of the red-cell population (i.e., $3 \mu \mathrm{g}$ anti-D $\mathrm{N}$ per $\mathrm{ml} \mathrm{RBC),} \mathrm{red-cell}$ survival was extremely short $\left(t_{\frac{1}{2}}, 35\right.$ minutes)

TABLE IV

Hemolytic effectiveness of isoantibodies

\begin{tabular}{ccc}
\hline \hline Serum & Amount of antibody & $\begin{array}{c}\text { Red-cell survival } \\
\left(\mathrm{t}_{3}\right)\end{array}$ \\
\hline & $\mu g / m l R B C$ & days \\
Anti-D & 0.54 & 24.5 \\
Anti-K $_{2}$ & 0.50 & 10.0 \\
Anti- $_{1}$ & 0.97 & 11.1 \\
Anti- $_{2}$ & 0.91 & 0.55 \\
Anti-K & 0.91 & 0.03 \\
Anti-D & 3.3 & 0.02 \\
Anti-D & 3.5 & 0.04 \\
\hline
\end{tabular}




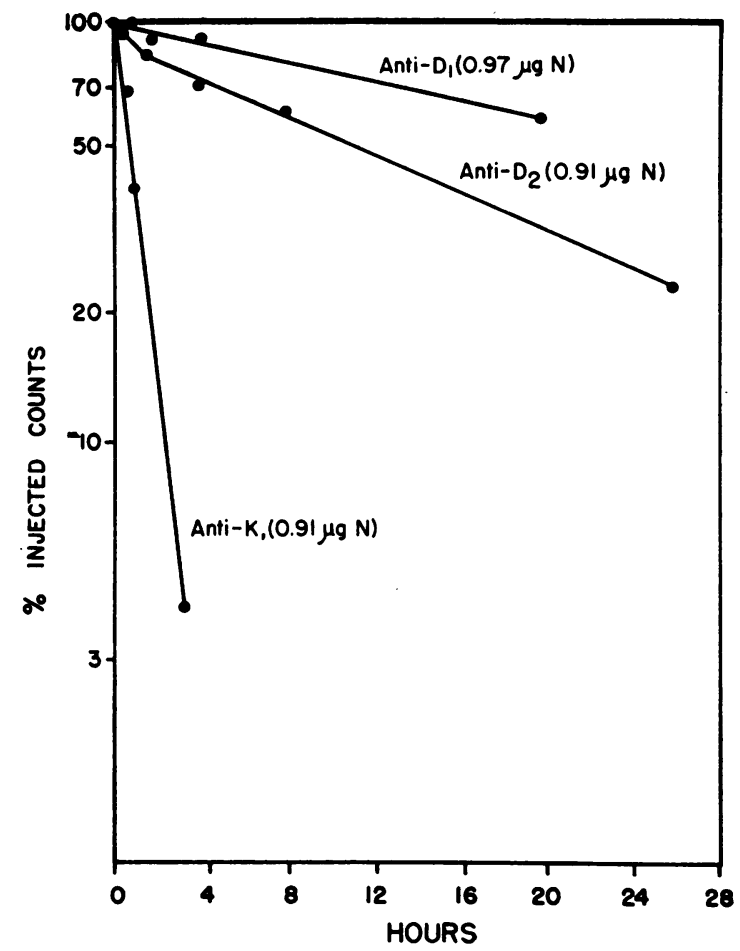

Fig. 4. Hemolytic efFectiveness OF ERythrocyte ISOANTIBODIES. The amount of red-cell-bound antibody was virtually identical in each experiment. Note, however, the marked variations in red-cell survival times.

and approached the minimal survival of red cells sensitized with noncomplement dependent univalent antibody (14).

b) Effect of antibodies with identical serologic specificities on red-cell survival. Three sera containing high-titer incomplete anti-D were ob-

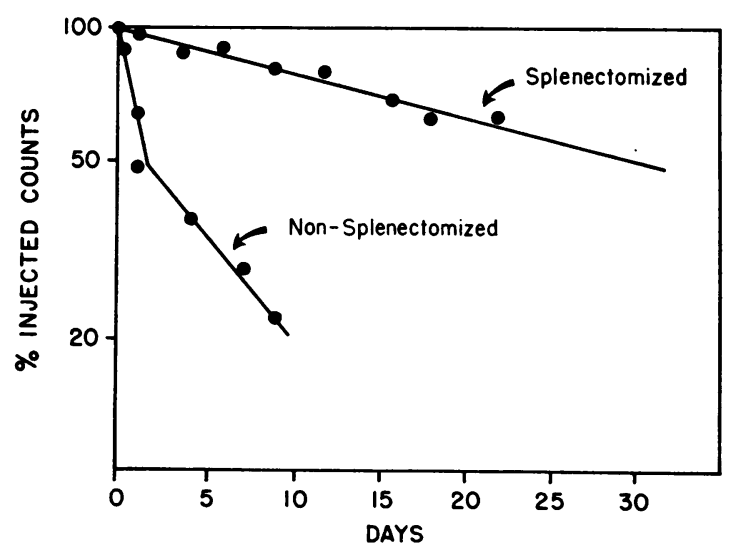

Fig. 5. EFFect of the spleEN ON SURVival of SENSITIZED RED BLOOD CELLS. The degree of red-cell-bound antibody was identical in each experiment $(1.11 \mu \mathrm{g}$ anti-D antibody $\mathrm{N}$ per $\mathrm{ml} \mathrm{RBC}$ ).

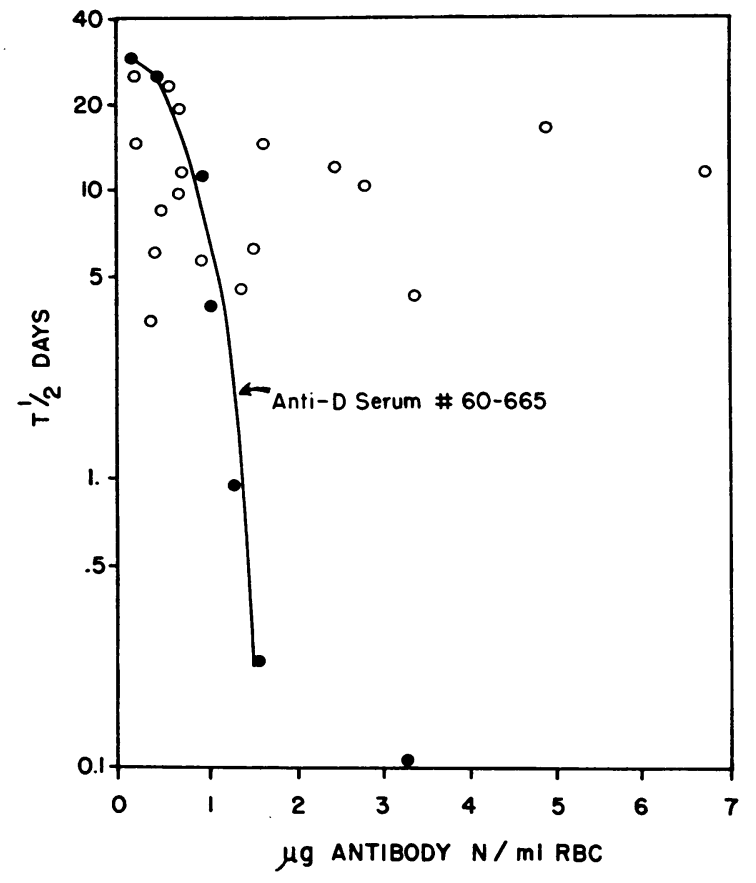

Fig. 6. Relation between amount of autoantibody AND SURVIVAl TIME OF AUtOLOGOUS RED CELLS IN THE patient (open circles). Closed circles represent results shown in Figure 3, superimposed for comparison.

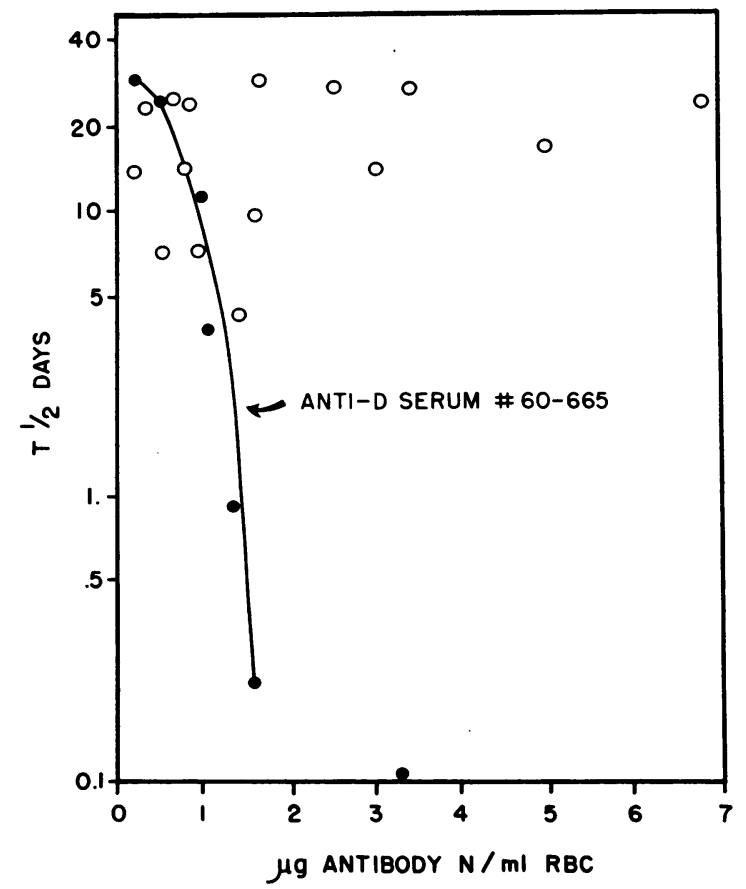

Fig. 7. Relation BETWEen amount of aUtoantibody AND SURvival time of the patient's Red CELlS IN A NORMAL RECIPIENT (open circles). Closed circles represent results shown in Figure 3, superimposed for comparison. 

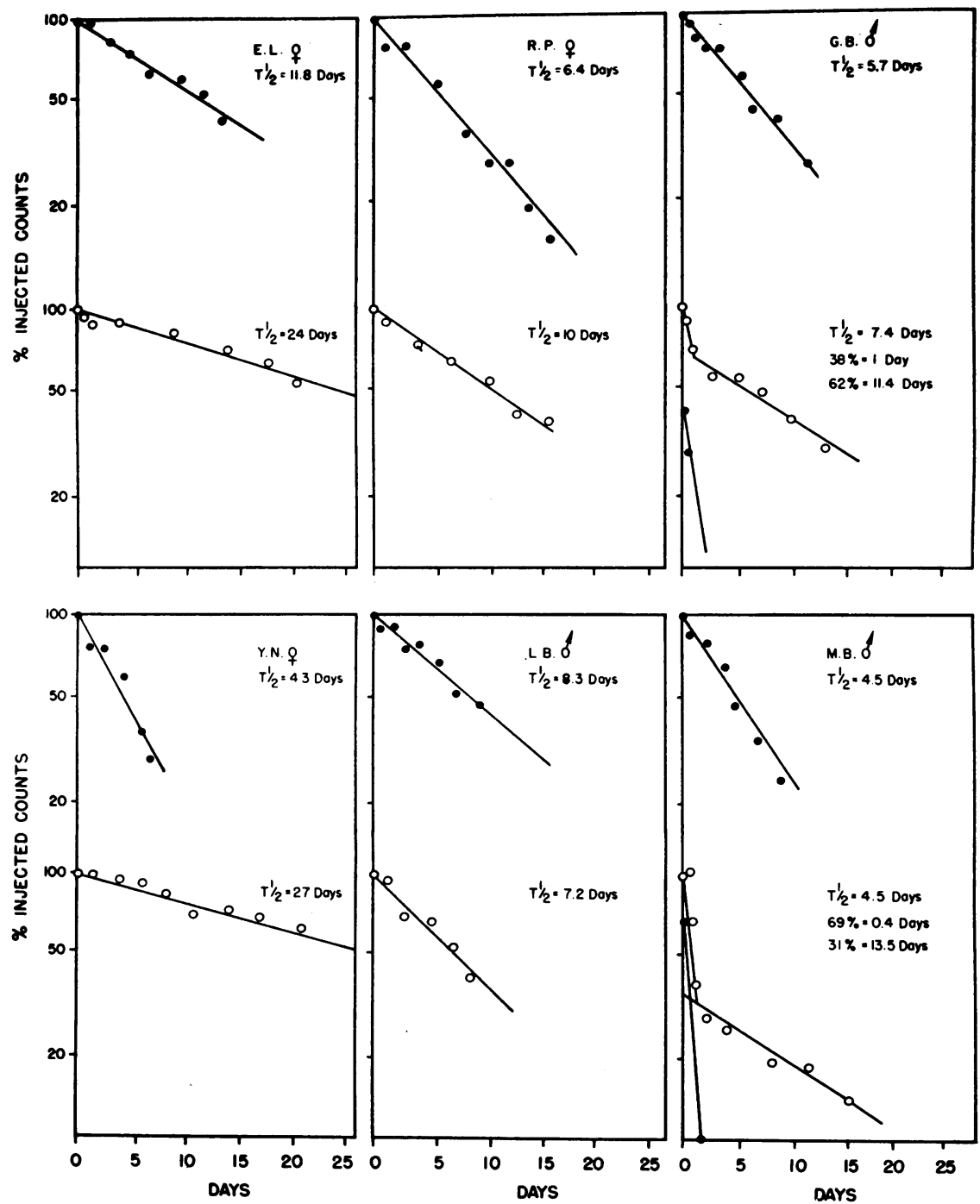

Fig. 8. Patterns of Red-cell destruction in autoimmune hemolytic anemia. The closed circles are the survival curves of autologous red cells in the patient (autosurvival), and the open circles are the results obtained when the patient's cells were injected into a normal recipient (isosurvival). Various patterns are represented. Left: short autosurvival time and normal isosurvival; Middle: short autosurvival and short isosurvival; Right: short autosurvival and short, two-component isosurvival.

tained from three separate persons (no. 60-665, San, and no. 3077). Normal Rh-positive red cells were treated with these antibodies as described above. Cells incubated with serum San were sensitized with $0.91 \mu \mathrm{g}$ antibody $\mathrm{N}$ per $\mathrm{ml} \mathrm{RBC}$; those sensitized with serum 3077 absorbed $3.5 \mu \mathrm{g}$ antibody $\mathrm{N}$ per $\mathrm{ml} \mathrm{RBC}$. Two samples of cells sensitized with serum 60-665 absorbed 0.97 and $3.29 \mu \mathrm{g}$ antibody $\mathrm{N}$ per $\mathrm{ml} \mathrm{RBC}$. The survival times $\left(t_{1}\right)$ of these cells were $14,1.0,264$, and 0.5 hours, respectively. Two sera containing high titers of incomplete noncomplement dependent anti-K obtained from two sensitized persons (no. CK-11 and 60-1214) were treated in a similar fashion. Cells sensitized with serum CK-11 absorbed $0.91 \mu \mathrm{g}$ antibody $\mathrm{N}$ per $\mathrm{ml} \mathrm{RBC}$, and those sensitized with serum 60-1214 absorbed $0.50 \mu \mathrm{g}$. The red-cell survivals $\left(t_{\frac{1}{2}}\right)$ were 45 minutes and 10 days, respectively (Table IV, Figure 4).

c) Survival of sensitized red cells in splenectomized recipients. Normal Rh-positive red cells were sensitized with $1.11 \mu \mathrm{g}$ anti-D antibody $\mathrm{N}$ 
per $\mathrm{ml} \mathrm{RBC}$ and labeled with $\mathrm{Cr}^{51}$; half of these cells was injected into a normal person, who also served as the RBC donor, and the other half was injecte 1 into an otherwise normal recipient whose spleen had been removed several years previously because of traumatic rupture. The red-cell survival in the first recipient had a $t_{\frac{1}{2}}$ of 3.8 days. whereas the $t_{1}$ in the splenectomized recipient was 30 days (Figure 5). A second experiment involving two other recipients, one normal and one splenectomized, was carried out with cells sensitized with $3.47 \mu \mathrm{g}$ anti-D antibody $\mathrm{N}$ per $\mathrm{ml}$ RBC. The survival times $\left(t_{\frac{1}{2}}\right)$ of these cells were 60 minutes and 16.4 days, respectively.

Autoantibodics. a) Autosurvivals. Cr ${ }^{51}$-labeled red-cell survival studies with autologous cells were done in 17 patients with AIHA. In three patients, two survival studies were done. The relationship between red-cell survival and amount of sensitizing autoantibody bound to the red cells is shown in Figure 6. There was no correlation between these two parameters.

b) Isosurvivals. With red cells from the patients with $\mathrm{AIHA}, \mathrm{Cr}^{51}$-labeled red-cell survival

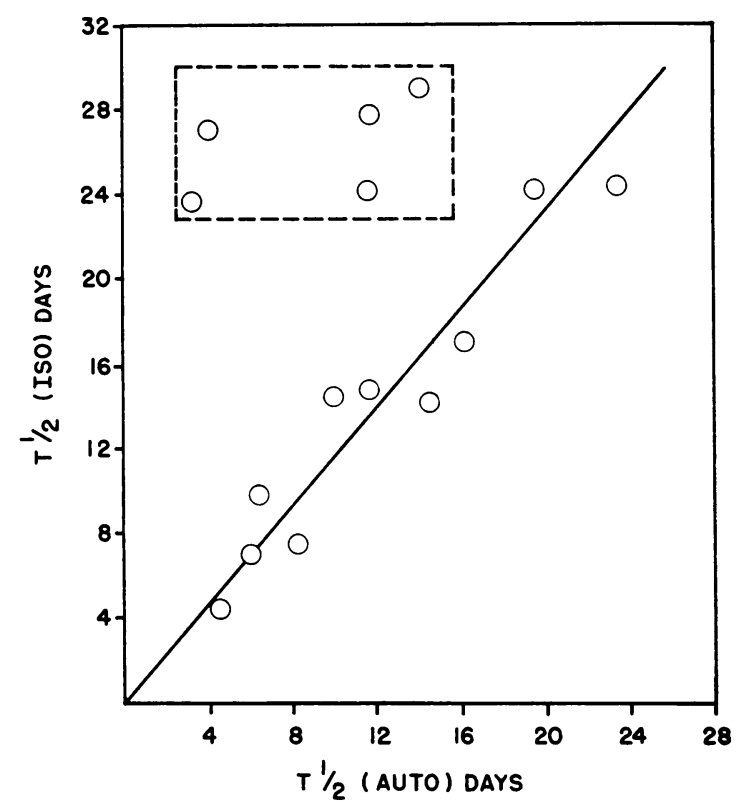

Fig. 9. Correlation between autostrival and isoSURVIVAL in AUTOIMMCNE HEMOLYTIC ANEMia. In ten patients, there was correlation between the two determinations (open circles connected by solid line), while in five, autosurvival was short, and isosurvival was normal (open circles within the dashed box). studies were performed in 15 normal recipients. These determinations were made simultaneously with the autologous red-cell survival studies described above. The results of these experiments are shown in Figures 7 and 8. Three patterns of isologous red-cell survival were found: normal survival (6), shortened survival (4), and a twophase curve with shortened survival (4). There was no correlation between the survival of these ceils and the amount of bound antibody. In most patients, the $t_{1}$ of the isosurvival was similar to that of the autosurvival (Figure 9). In five patients, however, there was actually an inverse correlation: normal isosurvival and short autosurvival. In three instances, the isosurvival was normal for 10 to 16 days, after which there was an abrupt disappearance of the remaining cells. This type of "collapse" curve was regarded as an indication of isosensitization of the recipient and was not taken into account in calculating the $t_{\frac{1}{2}}$ of the red-cell survival; the latter was obtained by projection of the slope of the original regression curve to $50 \%$ of the radioactivity contained in the first blood sample.

\section{DISCUSSION}

Isoantibodics. During the past decade, it has became clear that human red cells differ considerably in their isoantigenicity. For example, the antigen $D$ is a powerful immunizing substance, although $\mathrm{Jk}^{\mathrm{b}}$ and $\mathrm{s}$ are only weakly antigenic (14). Similarly, the antibodies provoked by these antigens vary considerably in their in vivo hemolytic activity; anti-D almost always produces severe hemolysis, whereas anti- $\mathrm{Lu}^{\mathrm{a}}$, although present in appreciable titer, may be without apparent effect on red-cell survival (14). Isoantibodies may thus be said to manifest at least two kinds of behavior: serologic and biologic.

Our experiments demonstrated that differences in biologic activity occurred, not only among antibodies of different serologic specificities, but also among antibodies with identical serologic characteristics. When red cells were sensitized with $0.97 \mu \mathrm{g}$ of anti-D nitrogen per $\mathrm{ml} \mathrm{RBC}$, their $t_{1}$ was 11 days, but red cells sensitized with 0.91 $\mu \mathrm{g}$ anti-K nitrogen per $\mathrm{ml} \mathrm{RBC}$ had $\mathrm{a}_{\frac{1}{2}}$ of only 45 minutes. The marked variations noted when antibodies of identical serologic specificity were tested are illustrated by a specimen of 
anti-I) that sensitized cells with $0.97 \mu \mathrm{g} N$ per ml $\mathrm{RBC}$, with a resulting survival time of 11 days $\left(t_{1}\right)$, whereas another specimen of anti-D, which sensitized cells with $0.91 \mu \mathrm{g}$ per ml $\mathrm{RCB}$, caused rapid destruction of red cells with $\mathrm{a}_{\mathrm{t}}$ of less than 1 day. These differences were apparently not due to the action of complement, since each of the antibodies studied was of the incomplete, noncomplement-fixing variety. Probably, these differences represent an intrinsic characteristic of a particular red-cell antibody that we shall refer to as "hemolytic effectiveness."

Hemolytic effectiveness seems to be a characteristic of red-cell antibodies that is independent of their serologic properties. The nature of this quality is unknown, but it may be the result of elution rate, electrostatic charge, steric configuration, and mode of union with antigen on the redcell surface. Although the effects of some of these factors are obscure, elution of antibodies from the red-cell membranes has been well-demonstrated in vitro $(10,15-19)$ and in vivo (20). A given antibody solution is composed of a heterogenous population of molecules with varying dissociation constants. The dissociation constants may have a broad range; hence elution of some antibodies will occur spontaneously (19), but others adhere to the red-cell surface despite repeated washings. Hughes-Jones and his associates (10) have suggested that "each successive dissociation of antibody from red cells should contain antibody with a progressively higher range of intrinsic binding constants." In our experiments, antibodies resisting elution despite serial washings were studied for their effects on red-cell survival. Thus the rapid in vivo hemolysis of the sensitized red cells was presumably due to antibody with relatively low dissociation constants. Nevertheless, since survival studies of the sensitized cells showed two-component curves, additional elution of antibody in vivo (20) probably contributed to the improved viability of a portion of the injected red cells. We found a linear relationship between the amount of red-cell-bound antibody (anti-D), as determined by the RAG technique, and the red-cell survival time (Figure 3 ). Since the points on this curve were derived from survival-time determinations in seven different normal recipients with their own erythrocytes, the principal cause of the shortened red-cell survival time was evidently the action of the antibody. Such factors as zygosity of the red cells, distribution of the antigen on the red-cell surface, variabilities in elution rates either because of antigenic factors or the number of antibody molecules on the red-cell surface, if important, would have disturbed the linearity of this curve.

The shape of the curve shown in Figure 3 illustrates several additional features of the interaction between isoantibody and red cells. a) Sensitization of erythrocytes does not necessarily lead to their premature destruction, as Mollison and Paterson (21) have already pointed out. In one experiment, the amount of anti-D absorbed by red cells was $0.54 \mu \mathrm{g} \mathrm{N}$ per ml RBC. This amount was enough to give a $4+$ direct antiglobulin test; nevertheless, survival of these cells was within normal limits. The limitations of red-cell-survival techniques with the $\mathrm{Cr}^{51}$ label are such, however, that appreciable diminution in the mean cell life may go undetected. "Normal" survivals of $\mathrm{Cr}^{51}$-labeled, sensitized red cells should, therefore, be cautiously interpreted $(22,23) . b$ ) The steep slope of the curve indicates that, above a certain level of sensitization (approximately $0.90 \mu \mathrm{g} \mathrm{N}$ per $\mathrm{ml} \mathrm{RBC}$ ), minute increases of red-cell-bound antibody induce pronounced effects on red-cell survival. Since antibody molecules possess electrostatic charges, minute increments in these coating proteins may conceivably result in membrane changes favoring phagocytosis of the sensitized cell by the spleen or liver. c) Complete saturation by antibody of the antigenic sites of the red cell is not necessary to cause their destruction at a maximal rate. When red cells absorbed approximately $30 \%$ of their anti-D combining capacity, their survival was measured in minutes. Thus, the zygosity of the sensitized red cells would not be a factor in their survival under these conditions.

That antibodies of the incomplete noncomplement-dependent type are not the sole factors leading to premature destruction of red cells was demonstrated by the striking differences between the disposal of equally sensitized red cells in normal and in splenectomized recipients. Although the survival of anti-D-sensitized cells in splenectomized recipient E.B. was shortened $\left(t_{\frac{1}{2}}, 16.4\right.$ days), she had mild autoimmune hemolytic anemia, which may account for this finding. These 
results confirm those of Jandl, Jones, and Castle (24) and of Hughes-Jones, Mollison, and Veall (25), who demonstrated by a surface counting technique that the principal site of destruction of red cells sensitized by anti-D is the spleen. Earlier studies had shown only hours difference between the survival of anti-D-sensitized red cells in splenectomized and in normal recipients. Since quantitative estimation of red-cell sensitization was not performed, however, comparing these results with ours is difficult. One problem, for example, is that in the absence of the spleen, cells sensitized with more than $3.5 \mu \mathrm{g}$ of anti-D N per $\mathrm{ml} \mathrm{RBC}$ may be removed from the circulation by the liver.

Autoantibodies. Because the RAG technique determines only the amount of rabbit antihuman globulin absorbed by sensitized red cells, the combining ratio of sensitizing antibody to rabbit antihuman globulin must be determined to calculate the amount of red-cell-bound human antibody. Utilizing two isotopes of iodine, we found this ratio for incomplete anti- $\mathrm{D}$ and anti- $\mathrm{K}$ antibodies of the $7 \mathrm{~S}$ variety. In the zone of extreme antibody excess, it was 7 to 1 , a value previously obtained immunochemically with soluble gamma globulin $(26,27)$.

The derivation of combining ratios in agglutinating systems would depend not only on the quantitative relationship between antigen and antibody, but also upon the availability of the cellular antigen and steric hindrances intrinsic to the system. These complications in applying the precipitin reaction to cell-bound antibody are illustrated by Rappaport's finding that even in large antibody excess, all antigenic groups of the tobacco mosaic virus failed to combine with antibody (28-29). In calculating the combining ratio by the RAG technique, however, determination of the intrinsic red-cell antigens is not employed, but rather the amount of antibody adherent to the membrane. This antibody actually functions in the RAG test as the antigen. Since the same number of antigenic (D) sites on the red-cell surface was found by the RAG technique as by the use of only $\mathrm{I}^{131}$-labeled anti-D, antigen-antibody reactions on the red cell surface must be equally available to both the red cell antibody and the RAG reagent. This evidence implies that unavailability of membrane antigens (either D or anti-D) is not a fac- tor in these reactions and accounts for the combining ratio's being the same as for soluble systems.

Because the amount of sensitizing antibody elutable from red cells is relatively minute in AIHA, determining the combining ratio directly is impossible. Attempts were therefore made to obtain additional information concerning the physicochemical properties of these autoantibodies. As Table III shows, there are a number of indications that these proteins are $7 \mathrm{~S}$ gamma globulins, and in no instance were reactions compatible with a macroglobulin type of antibody obtained. These findings agree with those of Fudenberg and Kunkel (30), who found that the circulating antibodies in AIHA of the warm variety were $7 \mathrm{~S}$ gamma $_{2}$ globulins. To simplify the comparisons between the autoantibodies of AIHA and the isoantibodies under investigation, we assumed that their combining ratio was also 7 to 1 .

Of the 17 patients with autoimmune hemolytic disease in whom autosurvival studies were done, 15 showed varying degrees of shortened erythrocyte life span, but the two patients who were in remission showed no abnormal hemolysis. No correlation was found between the values for redcell survival $\left(t_{\frac{1}{2}}\right)$ and the amount of autoantibody on the erythrocytes. Thus, patients with less than $1 \mu \mathrm{g}$ antibody $\mathrm{N}$ per $\mathrm{ml} \mathrm{RBC}$ were found to have highly abnormal degrees of hemolysis; patients with 5 or more $\mu \mathrm{g}$ antibody $\mathrm{N}$ per $\mathrm{ml} \mathrm{RBC}$ had only mild hemolysis. Dacie (31) has discussed the possibility that the autoantibodies of AIHA are less effective in causing red-cell damage than are isoantibodies. The data of the present experiments indicate, however, that small amounts of some autoantibodies may be associated with severe hemolysis (e.g., patient H.C. with $0.4 \mu \mathrm{g}$ antibody $\mathrm{N}$ per $\mathrm{ml} \mathrm{RBC}$ and a red-cell survival $t_{\frac{1}{2}}$ of 3.5 days), and some isoantibodies may have only moderate effects on redcell life span (e.g., red cells sensitized with 0.97 $\mu \mathrm{g}$ anti-D serum $6055 \mathrm{~N}$ per $\mathrm{ml}$ had a $\mathrm{t}_{\frac{1}{2}}$ of 11.1 days). Yet red-cell survival times of less than 1 day are never seen in AIHA (such a condition would be rapidly fatal), whereas isoantibodies may readily induce this degree of hemolysis, even when they sensitize erythrocytes to the same extent as autoantibodies.

The belief, widely held, that acquired hemolytic anemia can be differentiated from hereditary 
spherocytosis by determining the survival of an AIHA patient's red cells in a normal recipient, is not supported by the results of our experiments. The survival in normal recipients of red cells from patients with AIHA has been reported previously; in most of these studies, the Ashby method was used. Loutit and Mollison (32) and Lüdin (33) reported that such red cells survived as usual in normal recipients. Selwyn and Hackett (34), Owren (35), and Strumia and his associates (36) found an initial rapid disappearance of approximately $50 \%$ of the transfused red cells, but normal survival of the remaining cells. Of the 15 isosurvivals with the red cells of our patients, the red cells of 7 had normal isosurvivals, those of 4 showed a two-component behavior, and the remaining 4 had shortened isosurvivals. Moreover, the cells that showed a two-component curve had abnormally reduced survivals even in the "long" components of the curve. In contrast to Mollison's experience (37), our work showed no correlation between the severity of the hemolytic disease and the results of the isosurvivals. There is no reason to believe that red cells from patients with AIHA should have normal isosurvivals, since the rate of destruction of these cells in both the donor and the recipient is a function of the hemolytic effectiveness of the antibody, its rate of in vivo elution, and the action of complement. Although factors such as phagocytic activity of the spleen, fever, and infection undoubtedly further influence red-cell autosurvival in AIHA, in 10 of 15 patients there was a close correlation between auto- and isosurvival (Figure 9). This finding indicates that in these patients, autoantibody was the predominant factor influencing red-cell survival. In the remaining patients, such a correlation was not found ; we therefore assume that factors other than autoantibody contributed to the hemolytic process.

\section{SUM MARY}

The quantitative relationships between erythrocyte sensitization and survival were studied by the techniques of $\mathrm{Cr}^{51}$-labeled red-cell survival and the radioactive antiglobulin (RAG) test. The two major types of red-cell antibodies, isoantibodies and autoantibodies, have two types of behavior, serologic and biologic. Regardless of their serologic attributes, these antibodies had dis- tinctive effects on erythrocyte survival. Even antibodies of the same serologic specificity had different effects on in vivo hemolysis. This biologic attribute was termed "hemolytic effectiveness."

When either isoantibodies or autoantibodies from different individuals were studied, there was no correlation between the amount of antibody absorbed by erythrocytes and their survival time. In 10 of 15 cases of autoimmune hemolytic anemia, however, there was a positive correlation between the survival time of the patient's red cells in himself and their survival time in a normal person. This finding we interpreted as indicating that, in these cases, the major cause of the abnormal hemolysis was the autoantibody.

\section{ACKNOWLEDGMENT}

The expert technical assistance of Miss Jane Reinsborough is gratefully acknowledged.

\section{REFERENCES}

1. Fudenberg, H., I. Barry, and W. Dameshek. The erythrocyte-coating substance in autoimmune hemolytic disease: its nature and significance. Blood 1958, 13, 201.

2. Costea, N., R. Schwartz, M. Constantoulakis, and W. Dameshek. The use of radioactive antiglobulin for the detection of erythrocyte sensitization. Blood 1962, 20, 214.

3. Kidd, P. Elution of an incomplete type of antibody from the erythrocytes in acquired hemolytic anæmia. J. clin. Path. 1949, 2, 103.

4. Dunsford, I., and J. Grant. The Antiglobulin (Coombs) Test in Laboratory Practice. Edinburgh, Oliver and Boyd, 1949.

5. Lowry, O. H., N. J. Rosebrough, A. L. Farr, and R. J. Randall. Protein measurement with the Folin phenol reagent. J. biol. Chem. 1951, 193, 265.

6. Ouchterlony, O. Diffusion-in-gel methods for immunologic analysis in Progress in Allergy. Basel, S. Karger, 1958, vol. 5, p. 1.

7. Deutsch, H. F., and J. I. Morton. Dissociation of human serum macroglobulins. Science 1957, 125, 600.

8. Grubb, R., and B. Swahn. Destruction of some agglutinins but not of others by two sulfhydryl compounds. Acta path. microbiol. scand. 1948, 43, 305.

9. Helmkamp, R. W., R. L. Goodland, W. F. Bale, I. L. Spar, and L. E. Mutschler. High specific activity iodination of $\gamma$-globulin with iodine-131 monochloride. Cancer Res. 1960, 20, 1495. 
10. Hughes-Jones, N. C., B. Gardner, and R. Telford. The kinetics of the reaction between the bloodgroup antibody anti-c and erythrocytes. Biochem. J. 1962, 85, 466.

11. Read, R. C., G. W. Wilson, and F. H. Gardner. The use of radioactive sodium chromate to evaluate the life span of the red blood cell in health and certain hematologic disorders. Amer. J. med. Sci. 1954, 228, 40.

12. Wennesland, R., E. Brown, J. Hopper, Jr., J. L. Hodges, Jr., O. E. Guttentag, K. G. Scott, I. N. Tucker, and B. Bradley. Red cell, plasma and blood volume in healthy men measured by radiochromium $\left(\mathrm{Cr}^{51}\right)$ cell tagging and hematocrit: influence of age, somatotype and habits of physical activity on the variance after regression of volumes to height and weight combined. J. clin. Invest. 1959, 38, 1065.

13. Korngold, L., and G. van Leeuwen. The effect of the antigen's molecular weight on the curvature of the precipitin line in the Ouchterlony technic. J. Immunol. 1957, 78, 172.

14. Greendyke, R. M., and F. W. Chorpening. Normal survival of incompatible red cells in the presence of anti-Lu². Transfusion 1962, 2, 52.

15. Jandl, J. H., and M. E. Kaplan. The destruction of red cells by antibodies in man. III. Quantitative factors influencing the patterns of hemolysis in vivo. J. clin. Invest. 1960, 39, 1145.

16. Bowman, W. N., M. M. Mayer, and H. J. Rapp. Kinetic studies of red cell antibody combination and the resultant transfer of antibody from cell to cell during hemolysis. J. exp. Med. 1951, 94, 87.

17. Talmage, D. W. The primary equilibrium between antigen and antibody. Ann. N. Y. Acad. Sci. 1957, $70,82$.

18. Goodman, H. S., and L. Masaitis. The dissociation of hemolytic antibody from sensitized cells as measured by cell-to-cell transfer. J. Immunol. 1960, 85, 391.

19. Evans, R. S., M. Bingham, and P. Boehni. Autoimmune hemolytic disease. Antibody dissociation and activity. Arch. intern. Med. 1961, 108, 338.

20. Costea, N. V., M. Constantoulakis, and R. Schwartz. The in vivo behavior of specific erythrocyte antibodies in man (abstract). Blood 1962, 20, 792.

21. Mollison, P. L., and Paterson, J. C. S. Survival after transfusion of Rh-positive erythrocytes previously incubated with $\mathrm{Rh}$ antibody. J. clin. Path. 1949, 2, 190.

22. Berlin, N. I., T. A. Waldmann, and S. M. Weissman. Life span of red blood cell. Physiol. Rev. 1959, 39, 577.
23. Stohlman, F., Jr. The use of $\mathrm{Fe}^{59}$ and $\mathrm{Cr}^{51}$ for estimating red cell production and destruction: an interpretive review. Blood 1961, 18, 236.

24. Jandl, J. H., A. R. Jones, and W. B. Castle. The destruction of red cells by antibodies in man. I. Observations on the sequestration and lysis of red cells altered by immune mechanisms. J. clin. Invest. $1957,36,1428$.

25. Hughes-Jones, N. C., P. L. Mollison, and N. Veall. Removal of incompatible red cells by the spleen. Brit. J. Haemat. 1957, 3, 125 .

26. Jager, B. V., E. L. Smith, M. Nickerson, and D. M. Brown. Immunological and electrophoretic studies on human $\gamma$-globulins. J. biol. Chem. 1948, 176, 1177.

27. Kabat, E. A., and J. P. Murray. Comparison of human $\gamma$-globulins in their reactivity with rabbit anti- $\gamma$-globulin by the quantitative precipitin method. J. biol. Chem. 1950, 182, 251.

28. Rappaport, I. The antibody-antigen reaction. An hypothesis to account for the presence of uncombined antigenic sites in the presence of excess antibody. J. Immunol. 1957, 78, 246.

29. Rappaport, I. The reversibility of the reaction between rabbit antibody and tobacco mosaic virus. J. Immunol. 1959, 82, 256.

30. Fudenberg, H. H., and H. G. Kunkel. Physical properties of the red cell agglutinins in acquired hemolytic anemia. J. exp. Med. 1957, 106, 689.

31. Dacie, J. V. The haemolytic anaemias, congenital and acquired. Part II. in The Autoimmune Haemolytic Anaemias, 2nd ed. New York, Grune \& Stratton, 1962.

32. Loutit, J. F., and P. D. Mollison. Hæmolytic icterus (acholuric jaundice), congenital and acquired. J. Path. Bact. 1946, 58, 711.

33 Lüdin, H. Zur Differential diagnose hämolytischer Anämien. Acta haemat. (Basel) 1948, 1, 28.

34. Selwyn, J. G., and W. E. R. Hackett. Acquired haemolytic anaemia: survival of transfused erythrocytes in patients and normal recipients. J. clin. Path. 1949, 2, 114.

35. Owren, P. A. Acquired hemolytic jaundice. Scand. J. clin. Lab. Invest. 1961, 1, 313.

36. Strumia, M. M., L. Taylor, A. B. Sample, L. S. Colwell, and A. Dugan. Uses and limitations of survival studies of erythrocytes tagged with $\mathrm{Cr}^{51}$. Blood 1955, 10, 429.

37. Mollison, P. L. Blood Transfusion in Clinical Medicine, 3rd ed. London, Blackwell Scientific Publications, 1961. 